\title{
THE IMPACT OF GREEK CONCEPTS OF GOD ON THE CHRISTOLOGY OF CYRIL OF ALEXANDRIA
}

\author{
Roy Kearsley
}

\section{Summary}

Cyril transposes Neoplatonism rather than replicates it. Hence, his early struggle with Arianism and his fervour for the homoousios rule out full-blown ontological dualism in the Platonist manner. Rather, immutability and impassability do not mean immobility and impassivity, but active life-giving power and sufficiency to supply strength, powers which prove the co-equality of the Son with the Father. They support Cyril's resulting Christology: the Son 'appropriates' (Norris) human existence to himself in order to communicate life and victory. Immutability and impassability, paradoxically, nurture more a narrative Christology than a union of two static substances.

\section{Introduction}

Someone once said that all problems in Christian doctrine are an extension of the Christological question. Too simple perhaps, but it is surely true that all Christologies are wedded to a particular doctrine of God. This study is therefore a form of 'delayed Christology'. Before even reaching the Christology of Cyril of Alexandria we shall have to negotiate our way through three gates: Greek theology, immutability and impassability.

Some of the questions which vexed ancient thinkers like Plato and Plotinus are often viewed, unwisely, as quite irrelevant for Western thought today. However, they still permeate many of the great world religions. Is there a place of tranquillity free from the clashes of diversity and of inner conflict, a simple One, a place of escape from the Many? Can humans in any way approach God in his distant transcendence? Is there a point at which the flux and insecurity of human history come to rest? These questions are very much alive in non-western religious traditions, and moreover are finding a new incarnation in western cloned versions. Commentators have seen in the influential third-century Greek writer Plotinus an affinity both with Hindu thought and Islamic 
mysticism, ${ }^{1}$ and so there are some common roots to apparently very different world views.

Even without this kind of indirect relevance, the work of an ancient Christian writer like Cyril of Alexandria would still assume importance for us today as a paradigm of Christian eclecticism in a pluralistic world and an index of the complications that entails. Through such as Cyril we have an opportunity to let history teach us the art of the theologically possible. He mirrors for us both the pitfalls and the triumphs involved in attempting maximum effectiveness and impact in communication, a task repeatedly tackled by early Christian writers. They were thinking evangelists, and we need to look not just at the results of their labours but also at their spirit and methods. Determined to communicate the distilled Christian faith, they did not side-step intellectual challenges but made sorties into their own culture, risking ridicule more than they risked compromise. We can learn much from the ways in which they set about that task and the limits of its success.

\section{Early Christianity and Greek Views of God}

The question 'What is God in ancient Greek philosophy?' would furnish the perfect title for someone wishing simply to write a really long book. Aristotle, Plato and Zeno would each give a different answer, even if you were fortunate enough to get only one answer from any of them! We should therefore be a little suspicious of sweeping statements to the effect that Christians have grafted 'the Greek view of God' on to a simple, pristine and pure Christianity. Just as the philosophical schools of the early Christian centuries were eclectic within a broad spirit and rationale, so Christian 'philosophical theologians' did not import entire systems of thought from any particular philosopher or school. They did, however, plunder prevailing tools, language and conceptuality in their desire to communicate as clearly and meaningfully as they could what was really on their minds. For much of the time it was simply a case of speaking a native language born of a native conceptuality. E.P. Meijering states this perhaps a little too starkly when commenting that it '.. is misleading to suggest

${ }^{1}$ A.H. Armstrong, An Introduction to Ancient Philosophy (London, Methuen 1981) 183. 
that the Fathers chose a philosophy which emphasised God's unchangeability as the background of their theology. This would imply that they could easily have chosen a different philosophy if they had wanted to'.2 Over against this, we need to remember that they did, after all, contribute to the criticism and evolution of philosophy.

We certainly seem to be better placed with the work of Cyril than with some other Fathers, to judge what sources he consciously used. ${ }^{3}$ He tells us himself, for example, that he discerns a Christian view of God not only in some of Plato, but also in Plotinus (AD 205-270), the founder of Neoplatonist philosophy, and in his disciple Porphyry. ${ }_{4}$ However, we do not know how direct this use was. Certainly, behind the impact of Greek philosophy on Cyril's Christology lie some of the more enduring traits of the philosophical schools. These surface especially in his handling of the doctrine of the Trinity and the vexed questions of immutability and impassability.

Neoplatonism greatly refined and modified some of the tenets most strikingly shared by the earlier Middle Platonist writers who influenced second and third century Christianity. But it still left many assumptions intact. Amongst the more important of these were: the tension between the transcendent indivisible One and the many, the resulting remoteness and incomprehensibility of the highest principle, and Plato's preference for locating the real only in that which is perfectly at rest (with the consequent emphasis on divine immutability). Long ago W. Pater complained of such views: 'We might reasonably hold that motion covers all that is best worth being ... it means susceptibility, sympathetic intelligence, capacity...

2E.P. Meijering, 'What could be the relevance?', in God, Being, History. Studies in Patristic Philosophy (Amsterdam/Oxford, North Holland Publishing 1975) 149.

${ }^{3} \mathrm{~J} . \mathrm{M}$. Labelle in a fine survey of Cyril's sources has convincingly demonstrated the sympathetic eclecticism of Cyril: 'Saint Cyrille d'Alexandrie. Témoin de la langue et de la pensée philosophiques au Ve Siècle', in Revue des Sciences Religieuses 52 (1978) 135-58 (esp. 150, $156)$ and 53 (1979) 23-42.

4See Meijering, 'Cyril on the Platonists and the Trinity', in op. cit., (11427) $116 \mathrm{ff}$. 
yet to Plato motion becomes the token of unreality in things, our falsity in our thoughts about them' .5

However, one change of direction proved influential. Middle Platonists had adopted Divine Mind (nous) as First Principle or the Supreme One. This One corresponded to Aristotle's Unmoved Mover. It engaged in no activity outside of itself but was absorbed in its own self-contemplation. In Plotinus, however, the One lay beyond even Mind. It was the source of the divine Mind and itself neither a mind nor a form. It was even beyond Being itself, though not without existence. The Divine Mind, on the other hand, although remaining remote from the material universe, nevertheless contained a world of forms which informed diversity, Being, and living intelligences. Upon it depended Soul and Providence which provided a link with the material world.

Plotinus had, in fact, re-distributed the attributes of Middle Platonism's First Principle between the completely transcendent One and the Mind. The Platonist tradition was now beginning to show the strains involved in explaining the emergence of the many from the One without resorting to the notion of a creation willed in or with time by the Supreme Principle. The otherwise quite brilliant and elegant scheme of Plotinus now sounded uncertain at this one point.

It has been noticed that Augustine seized upon the distinctions thrown up by Neoplatonism in order to work them up into a Trinitarian formulation. He concentrated the whole of divinity in the One. The Divine Mind, too, could be identical to the Godhead, but more especially stand for the Son, the perfect expression of the divine productivity of the Father. 6 The Holy Spirit then resembled the higher Soul of the universe, the Bestower of life to embodied beings. But of course the Christian doctrine of the Trinity diverged from the thought of Plotinus in one unbending doctrine, traceable to the Nicaean homoousios. These hypostases did not actually reflect hierarchy of being but each equally stood for the one unbroken divine nature. The newer Greek way required that clear ontological divisions be held between the One, the Mind and

${ }^{5} \mathrm{~W}$. Pater, Plato and Platonism: A Series of Lectures (New York, Chelsea House 1983) (repr.), 22 (original date of publication not indicated).

6Armstrong, op. cit., 211. 
the higher Soul. By introducing the idea of a single level of divine being the Christian approach resisted the methodology and the form of the hypostases passed down by Plotinus. The legacy of the homoousios formed a rock upon which Platonist ideas could eventually only come to grief. 7

In view of all this, it is worth noting that Cyril's first major debate was with the later Arians, not with Nestorius. 8

Profound results flowed from this, relevant to our exploration here. He typified the instinctive Christian hold on a community of attributes within the homoousios between any higher Principles, a tendency which flattened the original clear ontologically hierarchical Neoplatonist scheme. If the Mind contained the variety of things in itself, and if the third principle, the Holy Spirit/Soul, was the bestower of life, ${ }^{9}$ and if there was unity of being (homoousios) between these and the One, then logically should not the deity of the One also imply its life-giving activity facing towards the world? But, if so, what happens to the earlier Platonist conception of a separated-out supreme One, incomprehensible, untouchable and remote? I hope to show that Cyril assumed just this kind of community of attributes between the Good (in Plotinus the indescribable inactive One), the Son and the Holy Spirit. Plotinus had said that the One is beyond act and therefore beyond life, but in Cyril the One acts as source and sustainer of all the changing objects of the world of time.

As we shall see later, Cyril radically adapted the superficially similar conviction of Plotinus himself that 'a perfection which is not creative, which does not produce or give out, is a contradictory and untenable conception'10 Plotinus spoke only of natural emanation not creation or

${ }^{7}$ See the excellent review by Moingt of Cyril's unsuccessful attempts to show that Plotinus was nearly a Christian Trinitarian: 'Cyril of Alexandria on the Platonists and the Trinity', op. cit., H. du Manoir gives a helpful list of Cyril's references to Plotinus and Porphyry: 'Le Problème du Dieu chez Cyrille d'Alexandrie', in Recherches de Science Religieuse 27 (1932) (385-407, 549-96) 389, Cf. J.M. Labelle, op. cit., passim.

${ }^{8}$ Du Manoir, op. cit., 593, well describes Cyril's work here as a 'transposing' of Platonist philosophy.

9J.M. Rist, Plotinus. The Road to Reality (Cambridge, CUP 1980) 27.

${ }^{10}$ A.H. Armstrong, 'Some Reflections on Cyril of Alexandria's Rejection of Anthropomorphism' Meijering, op. cit., 128-32, 131, n. 21. 
original act of the will. Moreover, Cyril had used the homoousios to re-unite the eternal, the Mind and the Spirit which long previously in Plato's original conception all described the One, the divine, only real being. 11

Cyril, or some source of his, also defied the Neoplatonist way of understanding Life and its relation to living beings. For Plotinus the life of the material world sprang from the Soul, though perfect and true Life dwelt only in the divine Mind, the highest Principle. 12 The One itself, it is true, was the Source of all life, in a giving-out which left that supreme One unchanged and undiminished. But this gifting of life flowed by natural emanation so that there was no activity, planning or choice on the part of the supreme One.13 It was a formless stream of life which poured forth by emanation, or radiation, from the One. ${ }^{14}$ But spiritual intelligences specifically owed their life more to the Divine Mind and material beings owed theirs to the Soul. In Cyril, however, we are going to meet again and again the conviction that God alone, and no other inferior level, directly maintains every kind of being different in kind from him and that he does this by his will, sustaining each individual creature in its own character. ${ }^{15}$

\section{Immutability}

Recognising, then, that at most Cyril 'transposes' Neoplatonism 16 rather than replicates it, we turn to the vexed question of the divine immutability inherited, seemingly intact, by him from the Platonists. Most of the time, Cyril's interest in it is Trinitarian, 17 like Apollinarius whose use of it he parallels. He does not so much wish to prove that God is unchangeable as to show that the Son too, like the Father, is beyond change. In the atmosphere of Platonism this status resembles that of the

${ }^{11}$ Plato so described by A. Kerrigan, St Cyril of Alexandria. Interpreter of the Old Testament (Rome, Pontificio Instituto Biblico 1952) 125.

${ }^{12} \mathrm{Cf}$. E. Gebremedhin, Life-Giving Blessing. An Inquiry into the Eucharistic Doctrine of Cyril of Alexandria (Uppsala University, 1977) 52.

${ }^{13}$ Armstrong, op. cit., 186.

${ }_{14}$ R.T. Wallis, Neoplatonism (London, Duckworth 1972) 66.

${ }^{15}$ Texts will illustrate this later but see du Manoir, op. cit., 554, 565.

16The helpful phrase of du Manoir op. cit., 593.

17Frances Young, From Nicaea to Chalcedon (London, SCM 1982) 185. 
divine Mind, the highest in the intelligible sphere and hence like the Supreme One itself in unchangeableness. The theme occurs clearly in Cyril's commentary on John (e.g. on Jn 1:2; 5:30; 6:27; 8.29). Cyril strongly resists the Arian teaching which renders the Son changeable like one of the creatures of the sensible world. He also contends in the Dialogues 18 that the Son must be unchangeable if he is to be the strength and refuge for us described in Psalm 89:1. So also in the correspondence with Nestorius he emphatically asserts the immutability of the Son (e.g. III.3), all the time sensitive that Antioch sees in the hypostatic union ( $\kappa \alpha \theta^{\prime} \quad \dot{v} \pi \delta$ ó $\left.\tau \alpha \sigma v\right)$ a threat to the divine unchangeableness. 19

Are we, then, simply looking at an anxious attempt to profile the Son in unmistakably divine terms familiar and congenial to all readers with even an elementary knowledge of Platonism and a sympathy with it? Is immutability just a stick for keeping ever so Hellenised Antiochenes at bay? Or does Cyril put the immutability concept to more creative, constructive and even Christianised use? I want to suggest that he is up to more than just driving off the suspicion of Arianism with a respected weapon. A useful illustration occurs in his comments on John 1:4 where he follows the text 'That which was made, in it was life'. To summarise his thought, the

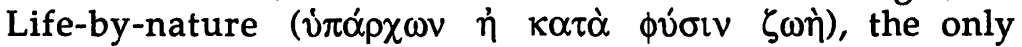
begotten Word of God, is in everything that is made. The one who is Life itself, bestows on them, in their multiplicity, being, life and motion. But he does this without himself changing into each of them, so ensuring that they will continue according to their natures, secure upon the one who transcends the limitations of having beginning and ending. ${ }^{20}$ True, Neoplatonist terminology stares up at us from this passage. Not only are the notions of indestructibility and deathlessness

${ }^{18}$ G.M. de Durand, Cyrille d'Alexandrie. Dieux Dialogues Christologiques. Introduction, Texte Critique, Traduction, et Notes (Sources Chrétiennes, 97) (Paris, Cerf 1964) 314-5. All quotations from the Dialogues will be from this edition. Also in J.-P. Migne, Patrologia Cursus Completus. Series Graeca, Paris 1857- (PG 75, 1279 A). The article makes use of various more recent editions of texts of Cyril.

${ }^{19}$ See also Letter to Succensus 1.6, 10; On the Creed 14, Answers to Tiberius 6, in L.R. Wickham (Tr., ed.), Cyril of Alexandria. Select Letters (Oxford, Clarendon Press 1983).

20PG 73, 85-7. 
keywords of Platonism in general, but also the bestowal of motion, being and life sounds like the multiple and changeable existences emanating from divine Mind. But Cyril calls the unchangeable being here the Creator (with all the biblical associations this has for him), the fountain of life, the bread of life. In short, unchangeableness goes with being the indestructible Life-giver, who is God the Creator in the Old Testament, and more particularly, Christ in the New Testament.

When he comes to John 1:9, describing the Son as the true Light, he makes the same kind of application. The Son is Light not by participation or by grace, but as 'the unchangeable and immutable good of the uncreated nature', giving light to created things. 21 If influenced at all by Plotinus, who saw Light as an incorporeal energy, Cyril is almost repeating the earlier sentiment. Certainly when, in his work against Julian, he interpreted the view of Pythagoras that 'God is one. .light ( $\phi \omega \tau \eta \dot{p} \rho)$ of heaven. . soul of everything', he took it to mean

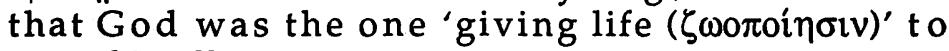
everything.22

The Word as unchangeable life-giver appeared again in the commentary upon the words of John 1:14: 'and the Word was made flesh'. Cyril stressed that the human being does not have of its own nature incorruption and immortality, because these things belong only to God. When the fall brought death it needed the Word, who gives life to all things, to unite himself to flesh and restore life, but not by changing into flesh, 'for the Godhead is far removed from all inconsistency and change into something else, because of its mode of being .23 In such ways immutability and life-giving activity conspicuously converge in Cyril's theology.

It is the same in his Sermon 45 on the Gospel of Luke. He examines the story of Jairus who asks the Saviour for the 'unloosing of death and the annulling of corruption'. Cyril comments: 'The supreme nature alone has immortality: and from it everything that is called into being borrows its life and

21 PG 73, 111.

22PG 76, 547 A D. See also P. Biurguière and P. Évieux, Contre Julian, Tome 1, Livre I et II. Introduction, Texte, Critique, Traduction et Notes, Sources Chrétiennes 322 (Paris, Cerf 1985) 189.

23PG 73, 157 D-158 A. 
motion.'24 Motion from immutability, life from deathlessness: it is all one to Cyril. He soon brings in Lazarus and asks the question: 'How do you think you can make (Christ) subject to death who is supreme over death: the overthrower of destruction and the giver of life?' Malley thinks that Cyril has the edge over popular Platonist schemes here, ${ }^{25}$ though even the apparently Christian intent of Cyril's work may partially have a Platonist assumption.

C. Dratsellas observes of Cyril that it is in our Saviour as the Incarnate Logos, that we have obtained the Spirit as a stable gift because Christ in His Divine Person initially gave His immutability to our nature'. ${ }^{26}$ I understand Dratsellas here to mean only that Cyril sees in the immutable Saviour's gift of life a gift of stability, or immortality, that resembles, by participation and grave, the divine unchangeableness. ${ }^{27}$ Cyril shares the Neoplatonist ideal of a stability consisting in contemplation of God, and this permeates both his anthropology and soteriology. But immutability also connects with life-giving grace, and functions as more than mere Platonist dogma. To Cyril nothing could be more disastrous than to undermine the vivifying power of the divine Word. For instance, he opposes the verb 'vitalize' to the Nestorian verb 'indwell' ${ }^{28}$ It has been said of Gregory of Nyssa, that in his thought, 'This Divine life, though perfectly unchangeable and eternal in the strict sense, is nevertheless conceived as an activity'.29 It was the same for Cyril. He attributes to the eternal and unchangeable One, an active life-giving function, a radical modification to the concept of a divine Mind, which

${ }^{24} \mathrm{R}$. Payne Smith (Tr.), Commentary upon the Gospel According to St. Luke by St. Cyril (Oxford, 1859) 187.

${ }^{25}$ W.J. Malley, Hellenism and Christianity. The Conflict between Hellenic and Christian Wisdom in the Contra Galilaeos of Julian the Apostate and the Contra Julianum of St Cyril of Alexandria (Rome, Università Gregoriana Editrice 1978) 285-6, 292.

${ }^{26}$ C. Dratsellas, Man in His Original State and in the State of Sin According to St Cyril of Alexandria (Athens, 1971) 26.

${ }^{27} \mathrm{C} f$. Dratsellas' later comment: 'Adam was not unchangeable because he being a creature was not infinite. Only God is infinite and therefore unchangeable' (ibid., 36). The created is changeable and therefore malleable in God's hand (Durand, op. cit., 205 n. 2).

${ }^{28}$ See Gebremedhin op. cit., 38.

${ }^{29}$ Gembremedhin op. cit., 48 , quoting D.L.B. Balas. 
was formerly simply the radiating source of multiple beings. Cyril's approach justifies the judgment that for the Fathers, 'God is immovable but not immobile'. 30 That is, they avoided in some measure, purely static ontology. Hence in his work Against Julian (Book I), Cyril can praise Hermes for the notion that God is 'the calm, the serene, the stable, the immutable, that which is peculiar to him alone, the One...'31 and then round off the description in his own words, 'vivifying

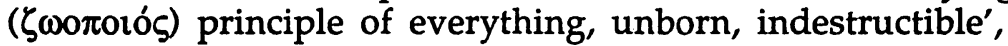
even though the word 'vivifying' does not appear in Hermes and the other Greek writers as quoted. He has already claimed that, 'they confess a unique God. . .without commencement, eternal, not subject to birth and corruption (but) life and lifegiver ( $\zeta \omega \eta \dot{x} x \alpha i \zeta \omega o \pi 010$ v), the creator of heaven and earth' (I.40).32 The idea of immutability does not function here to stress immobility or rest as we might expect. It underlines the conviction that God not only exists without beginning or end, but also animates all things as the indestructible principle of life.

As for Cyril's preoccupation with the Son as deathless life-giver, that tradition enjoys deeper roots than Neoplatonism. Christian writers of various degrees of 'orthodoxy', from Athanasius to Arius, had spoken of the union of the

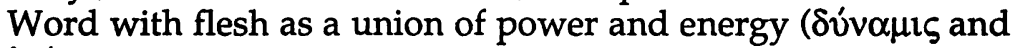

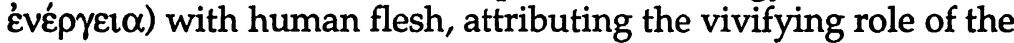
incarnate Word to this power and energy.33 Cyril's commentary on John's Gospel ripples with references to the Son's life-giving function, and these arise straight out of the texts themselves. ${ }^{34}$ They yield the following ingredients of Cyril's approach: The Word is the Life who gushes forth from the Father; the description which best suits the Word is 'Lifeby-nature'; The Word's immutability is an activity. $35 \mathrm{He}$ vanquishes death both as the deathless one and through the

${ }^{30}$ E. Timiadis, 'God's Immutability and Communicability', in T.F. Torrance (ed.), Theological Dialogue between Orthodoxy and Reformed Churches (Edinburgh, Scottish Academic Press 1983) 33.

${ }^{31} P G$ 76, 549 C - $552 \mathrm{~A}$.

32PG 76, $545 \mathrm{C}$.

${ }^{33}$ Gebremedhin, op. cit., 49.

${ }^{34}$ E.g. on Jn. $3.36 ; 6.27,35,36,41,55 ; 8: 20 ; 14: 11,20 ; 16: 7$. See also his commentary on Lk. 13.11; 18.31-4; 22.6, 17-22 in Durand op. cit.

${ }^{35}$ Gebremedhin, op. cit., 48. 
power of resurrection; consequently he is the Life-giver to all, especially those who look to him. For much of the time Cyril's argument for the Son's status as Life-giver parallels his Trinitarian defence of the Son's immutability. Commenting on Jn 6:40, he says of the Son's claim to raise the dead, that '.. giving life is a work proper to life, and since the Father is life, life surely will apply to him who belongs to the Father by nature, i.e. the only-begotten' 36

Here a now familiar stand-off with the Arians carries their grudging recognition of Christ's Sonship to what Cyril considers to be a truly homoousian conclusion. Life gushes forth from the Father. But it does so from the Son also.

Sacramental discussion in John 6:55 also provokes an assertion from Cyril that life-giving power belongs to Christ's flesh because that flesh is united hypostatically to the lifegiving Word.37 The logic of the sacrament then parallels the logic of the Son's raising of the dead. Divine life brings our bodies to immortality through participation in the sacrament of his flesh, just as life-giving power is communicated to that flesh through participation in the Word. This is the essence of Cyril's soteriology. 'From his side came a fountain of life vivifying the Mankind'. 38

We can now see why Cyril so frequently acquiesced in the principle of divine immutability and in particular the immutability of the Son. To Cyril it stood for the life-giving infinite resources of an active God, an idea quite opposed to divine immobility.

\section{Impassability}

Impassability is really the same question in another guise though an immediate problem of definition faces us. R.E. Creel lists several different senses of the word 'impassability' in early Christian thought. ${ }^{39}$ He includes: (1) lack of all emotion (2) motionlessness (3) freedom from distraction by fleshly

\footnotetext{
36PG 73, $545 \mathrm{C}$.

${ }^{37} P G$ 73, 580-1.

${ }^{38} \mathrm{C}$. Dratsellas, Questions of the Soteriological Teaching of the Greek Fathers (Athens, 1969) 68, attributing the quotation to De Incarnatione Unigeniti, PG 75 1465-8.

${ }^{39}$ R.E. Creel, Divine Impassibility. An Essay in Philosophical Theology (Cambridge, CUP 1986) 3, 4.
} 
pleasures or resolve and (4) will determined entirely by the one willing. Later on, however, Creel recognises that impassibility related to the Greek idea of 'autarkeia', or 'sufficiency', 'contentment':40 it 'signifies the nature of this God who is so wholly complete that he wants nothing. . .often identifiable with the immovable and absolute Deity who is indifferent to his creature'.

Cyril certainly has in mind the immovable, absolute and sufficient character of God when he speaks of the divine impassability but without the notion of indifference to his creatures observed by Creel. For Cyril, only a God who has need of nothing can actively bestow everlasting life. H.P. Owen recognises that although impassability during this period meant typically to Platonists the absence of sorrow, sadness or pain, it could mean incapable of change from external or internal cause (an amplification of immutability)'. If this is so, a habit of mind like Cyril's, which treats impassability as really an extension of immutability, to that degree shows a freedom from the control of typical Platonist assumption.

An example of Cyril's twinning of impassability and immutability crops up in his treatment of John 6:27.41 The passage targets the Arian notion that Christ's immutability is not natural but only an acquired likeness derived from the Father's act of sealing. Their purpose in this was to relieve the Father of 'passion' in begetting a Son. Cyril replies that they need not worry on this score, since 'the Father who does all things without passion will also beget without passion'. However, the chief point of likeness to the Father sought by both Cyril and Arianists for the Son was immutability. And the result of not recognising the Son's immutability by nature rather than acquisition, argues Cyril, was to be left with a saviour amongst humankind who had only attained freedom from passion, that is, 'perfection'. Immutability and impassability were clearly inseparable. A classic passage fuses the two qualities in a letter to Accacius:

the Word of God is unchangeable and immutable according to nature and insusceptible of all suffering according to his own nature. For the divine is impassible and by no means endures the

40Ibid., 6.

41 PG 73, 481-92. 
overshadowing of change, but is fixed in its own goodness and has unchangeable continuance in essence. 42

Here Cyril moves freely between the two qualities, so underlining impassability's character as an aspect of immutability.

In the specific matter of the nativity of the Son Cyril writes to a fellow bishop that the Son remained in the nativity 'what he was, God, immutable and inalterable according to nature'.43 Later he repeats the axiom, which is so important to him: 'For he remains what he is always, and is not changed, but instead never would be changed and will not be capable of alteration'.44 But then he immediately adds, 'Everyone of us confesses that the Word of God is, impassable, even though he himself is seen arranging. . .the sufferings that happened to his own body'. Impassability emerges as the natural corollary to immutability. Since impassability arises directly from the unchangeableness and life-giving sufficiency of God, Cyril more deliberately connects impassability with life-giving power. Commenting on John $4: 6$, he says, '. . the one who possesses in his nature power over all things, and is himself the

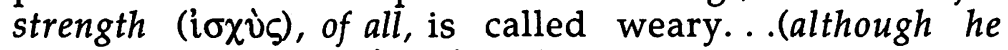

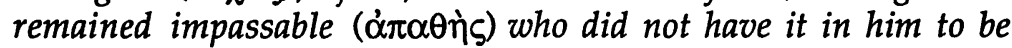
weary. . .) 45 (italics mine). Impassability here, plainly means not impassivity but the sufficiency and power to give strength in an active way.

A similar sentiment arises in his comments on John 14:20.46 The argument is rather lengthy but amounts to the following. The Son of God came to slay death. He would do this as the one unchangeable by nature and therefore sinless by nature, even in the flesh. The first dividend of the victory moved us from the death and from sufferings of the flesh inherited from Adam to the impassability and indestructibility of the second, heavenly, Adam. He has brought this potency of

42John I. McEnerny, St. Cyril of Alexandria. Letters: 1: Letters 1-50, 2: Letters 51-110 (Washington, DC, Catholic University of America 1987) $1,132$.

43 Ibid., 150.

44Ibid., 151.

45PG 73, 291-3.

46PG 74, 268-80. 
impassability into contact with changing, dying flesh and salvaged it from the claws of death.

As his Sermon 123 on Luke puts it, when the Word adopted the passibility and sufferings of the human body he united them with the indestructibility of his perfect immutable nature. 'He submitted to suffer. . .endured the death. . (and) trampled on destructibility'. ${ }^{47}$

$\mathrm{He}$ writes in a similar vein to the clergy in Constantinople 48 arguing strongly, if not indeed obsessively, for the impassability of the divine Word's nature, and at the same time argued for the passibility of the assumed human nature. The Life-giver somehow tasted death in his flesh without his ceasing to be life. The life-giving impassable nature still gave out life even though united to a flesh that knew death. Later on he simply says,...'(He) suffered in his humanity in his own flesh, but remained impassable in his divinity and lives for ever. He is life from the life of God the Father. Thus death was conquered, which dared to assault the body of life, and thus destructibility even in us is nullified and the strength of death itself is weakened. . .49

Life-giving impassability and human passibility to death combine forces to destroy the power of death. Cyril says something similar in his Third Letter to Nestorius: 'the onlybegotten God, impassible though he is in his own nature, has suffered in flesh. By nature Life and personally the Resurrection. . .he tasted death. . .With unspeakable power he trampled on death in order that he might blaze the trail for human nature's return to indestructibility. 50

One reason why the power of the Word's impassable nature features so strongly in Cyril's soteriology is that passibility went with sinning. In one of his letters he writes against unwarranted speaking of the Word's anointing by the Father. It could mean that the Word at some point needed sanctification and was therefore 'changeable by nature and would not be thought of as entirely free from sin or the power to err'.51

${ }^{47}$ Smith, op. cit., 569.

48 McEnerny, op. cit., 2, 30-1.

49 Ibid., 33.

50Wickham, op. cit., 23.

51McEnerny, op. cit., 1, 24. 
The remarks betray an assumption that changeableness (and I suggest, therefore passibility) is at the heart of sinfulness. Here, Cyril has not quite cleared his work of the Neoplatonist ethical ideal of acquiring similarity to the divine Mind in immutability. Cyril's comment on John 7:39 carries the same ring. In an explanation of Psalm 45:7 he sees the unchangeably righteous Christ as 'the only-begotten. . .lending us the stability of his own nature, because the nature of man had been condemned in Adam as powerless for stability. . .52 Writing to Succensus he asserts that it became vital for the Word of God to unite himself to a human flesh 'subject to decay and infected with sensuality. . .and (since he is Life and Lifegiver) that he should destroy the destructibility within it and curb the innate, the sensual impulses. ${ }^{53}$ Whilst sensual nature is not quite the same as passibility, it must imply it just as mortality implies changeability.

In his work On the Creed he pronounces that he, 'who suffered humanly has remained divinely impassable and always alive, because he is Life from God the Father's Life. This is the way Death has been vanquished, which has made bold to attack the body of Life; this is the way destructibility in us too is being annihilated and Death's power enfeebled.54 Also important here is the contrast that Cyril frequently draws between impassability and coporeality. Again it is not impassivity that he wishes to commend but the power and freedom of God, especially the Son, to bring aid to corporeal beings.

I think we have seen enough examples to say with some confidence that Cyril does not simply acquiesce in Platonist platitudes. Platonism leaves its tinge indeed upon his work, but this one thing is sure, that divine impassability in Cyril's exposition certainly does not mean 'impassivity' or inactivity, untouched by the troubles of changeable and fickle humanity. Impassability, for Cyril, goes out to transform the human condition and give life to it.

\section{Christology}

We can summarise the exploration so far by saying that the impact upon Cyril of Platonist thinking about God is more

52PG 73, 753 D - 756 A.

53Wickham, op. cit., 79 .

54Ibid., (On the Creed, 28), 126-9. 
complicated than we are usually led to believe. As philosophers were eclectic, so the Christian fathers in general were eclectic, and Cyril was not an exception. Like many, including Augustine, he did not simply allow Trinitarian belief to fall into the hands of Neoplatonism with its subtle hypostases. Nor did he permit all possible Platonist meanings in immutability and impassability to take root in his theology. In particular he declined to attribute immobility and impassivity to the Christian God. Equally, although he rushed to embrace the doctrines of divine immutability and impassability more ardently than almost any theologian today would, he also consecrated these qualities in a very selective way, so that they mainly functioned to support a soteriology, right enough, opened out in colours taken from Platonist thinking and depending upon ideas of contemplation, light and life familiar to most Platonist schools. All the same it was a soteriology and that alone made it un-Platonist! A.H. Armstrong soberly reminds us that Plotinus offered little hope to the ordinary person who could not be a philosopher: 'the weak and foolish as well as the wicked suffer in this world through their own fault and only get what they deserve, and they have no right to expect gods or good men to lay aside their own life and come to help them (Enn. III. 2.9).55 In this regard Cyril had wandered from Neoplatonism, stressing every bit as much as Augustine the lostness and moral inadequacy of human beings.

Then what does the view of God emerging from Cyril's theology say about Christ? It certainly presents Cyril with a dilemma. Whatever Christian uses adorn his presentation of God, he cannot avoid paradox. Henry Chadwick speaks of Cyril's 'not very illuminating conclusion: the Logos suffered impassibly ('z $\alpha \alpha \theta \varepsilon v \quad \dot{\alpha} \pi \alpha \theta \omega \varsigma)^{\prime} .56$ On the other hand, R.A. Norris has shown that even this sort of statement has some value because it shows that Cyril's Christology uses the language of appropriation. 57 Cyril does not take up his opponent Nestorius' challenge in order somehow to cobble

${ }^{55}$ Armstrong, op. cit., 195.

${ }^{56} \mathrm{H}$. Chadwick, History and Thought in the Early Church, Variorum Reprints (London, 1982) Paper XVI, 159.

57R.A. Norris, 'Toward a Contemporary Interpretation of the Chalcedonian Definition', in R.A. Norris (ed.), Lux in Lumine. Essays to honour Norman Pittenger (New York, Seabury Press 1966) 66-73. 
together two sets of attributes, a human and divine, but instead he states his Christology in the language of Nicaea, paraphrased by him as. ..'the. . .Word of God. . lowered himself to the point of self-emptying, was incarnate and made man'.58 The leading theme is kenosis, not in the modern sense but certainly in the sense that Christology should include a narrative expression. In a letter opposing the Nestorian Christological model of 'indwelling' Cyril settles the case for Christ's unity by appeal to the Philippians 2 kenosis passage. 59 The divine, only-begotten Word of God takes a body from the Virgin, makes it his own, offering himself in an odour of sweetness to the Father, 60 and 'no longer showed himself in the glory of Godhead'.61 This passage answers the reluctance of Nestorius to have the eternal Son praying.62 Nestorius, Cyril complains, has ejected from human nature the one who reached to it by self-emptying. Scripture announced that '... the Word of God would humble himself to emptiness. ..'63 The kenosis is not, for Cyril, a change of the deity as some more modern kenotic theories hold, but the assumption, by the Son, of humanity with a resulting change in the human condition, both of the humanity assumed by the Word and the humanity of those joined to him.64

This background is very important. It especially highlights the focus of Cyril's Christology on the unity of Christ. In a typical statement along such lines Cyril says, the Word's 'assumption of human nature took place for the overthrow of death and destruction. . . His holy flesh bore in it the power and activity of God. For it was his own flesh, and not that of some other Son beside him, distinct and separate from him. ..'65 The Word is one, not of course by conversion into humanity, because it is 'inconvertible ( $\alpha$ ' $\tau \varepsilon \pi \tau \circ \varsigma$ ) and

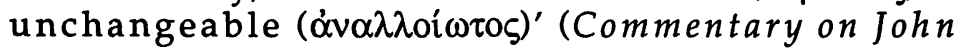

58Ibid., 69.

59McEneny, op. cit., 1, 22-3.

${ }^{60}$ Letter to Valeran, McEneny, op. cit., 1, 217.

${ }^{61}$ Smith, op. cit., 544.

62Ibid., 95.

63Ibid., 141. See also Sermon 104 (on Luke 14.15-24).

${ }^{64} \mathrm{~B}$. De Margerie, Introduction à L'Histoire de L'Exégèse des Pères Grecs et Orientaux (Paris, Cerf 1980) 286.

65Ibid., 452. 
20:30,31).66 The self-emptying, rather, is really a 'taking' without change of the deity and resting upon the life-giving immutability of the Son. It describes the changeless Lifegiver's taking of flesh and vivifying it.

The almost physical way in which Cyril expected the divine, changeless self-sufficiency to bring life to the world compelled that commitment to Christ's unity for which he is so famous. Changeless and changeable must touch. Impassable and passable must combine, the higher taking to itself the lower and transmitting deathlessness to it. One very striking example appears in Cyril's commentary on John: '. . .we believe the body of Christ to be life-giving, since it is the temple and home of the Word of the living God, possessing all his energy, so we declare it to be also an agent of light; for it is the body of him who is by nature true light' 67

Cyril here, as so often, angles his explanation towards the salvific value of the eucharist, but the Christological significance of Christ's earthly historical body still comes first. It enjoys life-giving potency because it is so intimately united to the Divine. The passage incidentally illustrates the analogy of energising light with energising life that we noticed earlier. The idea of theophany has also been seen in Cyril's treatment of the human body of the Word so that life, glory, power and energy are attributes of the humanity of Christ as well as of the deity.68 The flesh does not continue to be destructible and mortal but 'since it is the flesh of the indestructible God-that is to say, his very own flesh-he has placed it above death and destructibility'.69 This is not Apollinarianism if only because natural life does not flow from Logos to body, since Cyril seems to accept the idea of suffering in Christ's human soul. It does

66PG 74, 757 C-D.

${ }^{67} \pi \rho{ }^{6} \xi \varepsilon v 0 \varsigma$ rendered here not by its more strictly correct 'patron' but by the more general 'agent'. Further discussion of Cyril's notion of Christ's life-giving body appears in A Grillmeier, Christ in Christian Tradition, 1 (Revised Edition) (London, Mowbrays 1975) 476, with examples in $n .11$.

${ }^{68} \mathrm{Gebremedhin,} \mathrm{op.} \mathrm{cit.,} \mathrm{36.} \mathrm{See} \mathrm{also} \mathrm{the} \mathrm{significance} \mathrm{of} \mathrm{the} \mathrm{term} \mathrm{idios}$ in Cyril's Christology, in Gebremedhin, op. cit., 36-8, and A. Louth, 'The use of the Term idios in Alexandrian Theology from Alexander to Cyril', in E.A. Livingstone (ed.), Studia Patristica XIX (Leuven, Peeters Press 1989) 198-202.

${ }^{69}$ Durand, op. cit., Le Christ Est Un, 323. 
not, in other words, result in a 'third thing'. It does, however, underline the extent to which the unity of Christ's person dominates Cyril's Christological landscape.

Christ's divine nature, says Cyril in his commentary on John 17:22, '. . .when once received into the body of the Word was regarded as one with him. For Christ is one and the Son is one'.70 There follows a further explanation of mystical and eucharistic unity between the Word and the branches, ending with the conclusion that, 'For in no other way could that nature which is subject to destruction be lifted up to indestructibility but by the coming down to it of that nature which is above all destructibility and change ( $\pi \alpha \rho \alpha \lambda \lambda \alpha \gamma \eta \hat{\varsigma})^{\prime} 71$ The 'coming down' here speaks both of kenosis and of unity in the Christ, of appropriation, as Norris would have it. The whole structure, however, rests on the bedrock of unchangeableness and indestructibility, with their power to generate stability and immortality in human beings. As Cyril states it when describing the crucifixion in his Commentary on John 19:16,18: 'For the God who is above all was all-sufficient, so dying for all. . the author of everlasting life subduing on his own the power of death'.72

Christologically, then, Cyril's use of immutability and the Life-Giver motif in a kenosis framework leads straight to a stress on the unity of Christ, with the Son being the primary Subject. The evidence seems to favour those who judge Cyril's Christology to be natural to his way of thinking and not a device invented to squash Nestorius. It also explains why the unity is indispensable even in the early days of his writing, when it was the Arianists who troubled him most. As we have seen, most of the pieces are in place with Cyril's commitment to Nicaea. Already in his comments on John 15:173 he sees the unity of Christ naturally stemming from the soteriology taking shape in his hands from Athanasius. He focuses once more upon the believer's participation in the indestructible life of Christ's body, his flesh and blood. That this can be, results from the Word taking flesh and so transforming it into a living principle. The contact of that body with believers, through the

$70 P G$ 74, 561-4.

71PG 74, 564-5.

$72 P G 74,653$.

73PG 74, 332-4. 
power of the Holy Spirit overwhelms destructibility in them and pledges final resurrection. What underwrites these promises? Cyril answers: 'He not only invested his own flesh with the power of raising those who are asleep, but the divine and incarnate Word, being one with his own flesh says, I will raise him up...For Christ is not severed into a duality of sons, nor. . .his body. . .alien from the only-begotten'. We are not looking here simply at the joining of static substances but at the narrative of the divine Word who takes the initiative ${ }^{74}$ and who unites flesh to himself so that the very contact generates life. R.L. Wilken underlines this narrative with his claim that 'the Adam-Christ typology plays an even more decisive role than in Irenaeus, for it is both a key theological concept and a versatile and plastic exegetical key' ${ }^{75}$ One might not want to take the whole eucharistic package, or the soteriological one for that matter, but nor can the 'static ontology' charge be wholly made to stick. Of course when the controversy with Nestorius finally takes over in Cyril's life, his narrative Christology comes to a crisper and more refined statement. In the second letter to Nestorius (ch.3) he says, 'We do not mean that the nature of the Word was changed and made flesh or, on the other hand, that he was transformed into a complete man...but instead we affirm this: that the Word 'hypostatically' ( $\kappa \alpha \theta$ ' $\dot{\pi} \pi$ ó $\tau \alpha \sigma \iota v)$ united to himself flesh

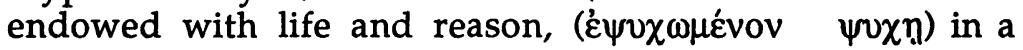
manner mysterious and inconceivable' ${ }^{\prime 76}$ All the mature Christology of Cyril is here. The unity model comes out against that of 'indwelling' argued by Nestorius; it springs from the action of the divine Word as subject (even though Cyril seems to have got off on a quite different foot with the introduction of the term 'nature' [ $\phi v \sigma l \varsigma]$, the unity extends not just to corporeal flesh and blood but also to the soul $(\psi v \chi \eta)$; and lastly, the long-standing recognition amongst the fathers of the mystery of the incarnation, including its secret potency, rounds off the account. And, shortly afterwards in chapter 5, the soteriological thrust of Cyril's Christology reappears in the

${ }^{74}$ Gebremedhin, op. cit., 39.

${ }^{75}$ R.L. Wilken, 'Exegesis and the History of Theology. Reflections on the Adam-Christ Typology in Cyril of Alexandria', in Church History 35 (June 1966) 139-56, 142.

76Wickham, op. cit., 5-7. 
connected stream of his discussion: '... within the suffering body was the Impassable. We interpret his dying along exactly comparable lines. The Word of God is by nature immortal and incorruptible, is Life and life-giving'...77 That unswerving allegiance to a 'vivification principle' led Cyril directly to a model of unity in Christology, a model that could bear such soteriological weight, but moderated by the recognition of a human soul $\left(\psi v \chi \eta^{\prime}\right)$ in Christ. This does not take us any further in weighing the reputed shortcomings of Cyril's Christology. It does not, for instance, settle the question whether either his soteriology or his Christology really integrated satisfactorily the human soul and rational life of Christ. However, the abandon with which Cyril charged into the notion of a full taking of passible humanity, fortified by the kenosis idea and the unchangeableness of the divine Word, suggests at least that he was not threatened by the idea. As we have seen, his account of the hypostatic union in II Nestorius 3 assumed the taking of a human soul in the incarnation as a key axiom.

But what of Chadwick's implied question, mentioned earlier, of what the Word's suffering impassably might possibly mean?78 Christology today seems to be stripped of Cyril's discredited analogy of the human soul dwelling impassably in a body susceptible to pain. And yet, the problem assumes less significance if impassability functions more to denote the complete unchanging adequacy of the divine Word as giver of life than as a trademark of infinite transcendence or 'negative theology'.

Each of these Christological themes deserves a treatise in itself, but especially does the question of Cyril's use of $\phi v 0 r s$ and the 'static ontology' said to have so marred his influence upon the solution of Chalcedon. However, at the heart of that discussion lies a rather stereotyped understanding of the divine immutability which simply translates it unquestioningly from Platonist sources to Cyril's theology. As we have seen, the attribute functions in Cyril's treatment rather more actively than that. There are, therefore, many additional tracks to follow beyond the subject handled in this article.

77Ibid., 7-9.

${ }^{78}$ See Chadwick, op. cit., 162, for a pedigree in Plotinus (' $\alpha \pi \alpha \theta \eta \pi \alpha \theta \eta^{\prime}$ ) and his view of the soul, for this statement in Cyril. 


\section{Conclusion}

An analysis of the impact of certain aspects of Platonist theology on Cyril reveals that Christian faith did not enfold philosophy within itself without a modifying process. At the level of the doctrine of the Trinity, the reworking influence of Nicaea was profound. Neoplatonism could not solve the mystery of the Trinity any more than it could the mystery of the incarnation, but nor could it dissolve it, or fail to provide a useful language in which to express it. Once that language was bent to the demands made upon it by Nicaean thought a less than Neoplatonist concept of deity emerged. It was in fact the Trinitarian question that worried Nestorius. The Cyrillian hypostatic union seemed to him to introduce passibility to the Son and therefore the Godhead, so-reawakening the spectre of subordinationism. ${ }^{79} \mathrm{He}$ need not have worried. The integrity of the Trinity is one of the reasons that Cyril seems so constantly wedded to the inherited philosophical language about God when describing the Word. He was certainly not going to go down in history as an Arianist!

What Cyril does with the ideas of impassability and immutability matters very much to modern theology. Cyril's work verifies the judgment of G.L. Prestige that, in the fathers, impassability does not 'mean that God is inactive or uninterested, nor that he surveys existence with Epicurean impassivity...' Rather it shields God from being 'dependent on the created universe and thus at best only in possession of concurrent power. . .In that case God ceases to be the ground of all existence. . '80 At the same time it seems to me a correct view which sees in Cyril's approach a determined attempt to bring in passibility as one of the conditions assumed by the divine Word in the kenosis.81 It seems precipitate to rush to the rescue of Cyril by simply off-loading impassability altogether, as some current trends seem to demand, or by changing the terms of talk about God so that we do not need to bother

${ }^{79}$ Chadwick, op. cit., 158.

${ }^{80}$ G.L. Prestige, God in Patristic Thought (London, SPCK 1952) 7.

${ }^{81}$ Richard Bauckham, in my view, handles this aspect of his discussion very well in 'In Defence of the Crucified God', in Evangel 9:1 (Spring 1991) (13-6) 13, 14. 
ourselves with such questions.82 With the legacy of the Greek writers Cyril gave the inherited language and conceptuality a soteriological and Christological twist which for all its faults was intended to underline the uniqueness and sufficiency of Christ for the entire human dilemma. Any attempt to resolve the question of divine immutability in Christian thought must, to be faithful to the New Testament, at least follow him in that.

I have not even tried to evaluate or solve the various and serious questions of ambiguity or Christological inadequacy in Cyril which stem from the material we have examined. But I trust the enlarged picture does him more justice than he has tended to receive.

82Such seems to be the bolt hole of dialectical theology just too often. A more thoughtful and helpful attempt to change the terms appears in A. Torrance, 'Does God Suffer? Incarnation and Impassibility', in T. Hart and D. Thimell (eds.), Christ in our Place. The Humanity of God in Christ for the Reconciliation of the World (Exeter, Paternoster 1989) 345-68, but I think his claims for some modern theology that it has shaken off a philosophical model in favour of the God of revelation is exaggerated. The 'personalist' model is every bit as indebted to a philosophy as any other model, even if Christian influences have helped to form that philosophy (as argued by Colin Gunton in The Promise of Trinitarian Theology (Edinburgh, T. \& T. Clark 1991) ch. 5. 